\title{
Dinoflagellate Ceratium symmetricum Pavillard (Gonyaulacales: Ceratiaceae): Its occurrence in the Hooghly-Matla Estuary and offshore of Indian Sundarban and its significance
}

\author{
Anirban Akhand ${ }^{1}$, Sourav Maity ${ }^{2}$, Anirban Mukhopadhyay ${ }^{3}$, Indrani Das ${ }^{4}$, Pranabes Sanyal ${ }^{5}$ \& \\ Sugata Hazra ${ }^{6}$ \\ 1,3,5,6 School of Oceanographic Studies, Jadavpur University, Kolkata, West Bengal 700032, India \\ 2 Indian National Centre for Ocean Information Services (INCOIS), Ministry of Earth Science (MoES), Govt. of India, "Ocean Valley", \\ PB No. 21, IDA Jeedimetla PO, Hyderabad, Andhra Pradesh 500055, India \\ ${ }^{4}$ Department of Botany, Midnapore College, West Bengal 721101, India \\ Email: ${ }^{1}$ anirban_akhand@rediffmail.com (corresponding author), 2srv_maity@rediffmail.com, ${ }^{3}$ anirban_iirs@yahoo.com, \\ ${ }^{4}$ ms_indranidas@yahoo.co.in, ${ }^{5}$ pranabes@gmail.com, ${ }^{6}$ sugata_hazra@yahoo.com
}

The Sundarban, a Biosphere Reserve, constitutes a complex ecosystem comprising one of the three largest single tracts of mangrove forests of the world. As neighboring countries, India and Bangladesh share the territories which cover the areas of the Sundarban. The Indian Sundarban $\left(88^{\circ} 02^{\prime}-89^{\circ} 06^{\prime} \mathrm{E} \& 2^{\circ} 13^{\prime}-\right.$ $22^{\circ} 40^{\prime} \mathrm{N}$ ) including the forest and nonforest parts consist of three major estuaries. The biodiversity richness of the Sundarban has been reported by many researchers. However, there are very few studies on phytoplankton diversity (Santra et al. 1991; Mitra et al. 2003; Sen \& Naskar 2003). Phytoplankton are the

Date of publication (online): 26 July 2012

Date of publication (print): 26 July 2012

ISSN 0974-7907 (online) | 0974-7893 (print)

Editor: S.C. Santra

Manuscript details:

Ms \# 02530

Received 29 July 2010

Final received 21 June 2012

Finally accepted 25 June 2012

Citation: Akhand, A., S. Maity, A. Mukhopadhyay, I. Das, P. Sanyal \& S. Hazra (2012). Dinoflagellate Ceratium symmetricum Pavillard (Gonyaulacales: Ceratiaceae): Its occurrence in the Hooghly-Matla Estuary and offshore of Indian Sundarban and its significance. Journal of Threatened Taxa 4(7): 2693-2698.

Copyright: (c) Anirban Akhand, Sourav Maity, Anirban Mukhopadhyay, Indrani Das, Pranabes Sanyal \& Sugata Hazra 2012. Creative Commons Attribution 3.0 Unported License. JoTT allows unrestricted use of this article in any medium for non-profit purposes, reproduction and distribution by providing adequate credit to the authors and the source of publication.

Acknowledgements: Authors wish to thank Mr. Bijan Kumar Saha Former Senior Deputy Director General, Geological Survey of India for his cooperation in this work. The authors are also grateful to National Aeronautics and Space Administration for providing the SST data through the Ocean Color website.

OPEN ACCESS | FREE DOWNLOAD
Abstract: The Sundarban is the largest mangrove ecosystem, which is presently vulnerable to climate change related impacts. The western part of it falls in the state of West Bengal between the estuaries of the Hooghly and Ichamati-Raymongal Rivers. The diversity of the genus Ceratium Schrank and the related physicochemical parameters such as Sea Surface Temperature (SST) was studied in the Hooghly-Matla estuary and offshore. Five species of bio-indicator dinoflagellate, Ceratium were identified in the bloom-forming season. The species are: $C$. furca, C. fusus, C. symmetricum, C. trichoceros and C. tripos. C. symmetricum was not previously reported from the Indian part of the Sundarban and is now found in low abundance. The other four species are less sensitive to warming or rise in SST. A comparative study of the day time SST from the satellite images of the year 2003 to 2009 of the months of January and February reveals a rising winter SST. Compared to the previous years, the increase in temperature can be one of the causative factors to explain the lower abundance of $C$. symmetricum compared to the others. With further rise of the SST, there is a possibility that this species may no longer be found in abundance in the western part of adjoining Hooghly-Matla estuarine system.

Keywards: Biological indicator, Ceratium, phytoplankton, sea surface temperature, Sundarban.

foundation of the foodweb in the marine ecosystem as they perform the critical ecological function of primary production (Nielsen \& Jensen 1957; Banerjee \& Santra 2001, Verlencer \& Desai 2004). The knowledge of phytoplankton species diversity is crucial for any ecological or eco-physiological work on marine phytoplankton. Phytoplankton are highly sensitive to environmental changes. Their community composition, biomass and shifts therein represent an excellent tool to interpret the dynamics of a pelagic ecosystem, transformation, cycling of key elements and the impact on coastal water quality. Phytoplankton also help to detect variations induced by river discharge, eutrophication, pollution and even 
certain unusual climatic phenomena (Lepisto et al. 2004; Paerl 2006). Ceratium Schrank, an armoured dinoflagellate genus has been considered a biological model for a wide range of studies as utilized by TuninLey et al. $(2007,2009)$. One of the several advantages offered by this genus is that identification of species level is more feasible than other phytoplankton group (Tunin-Ley et al. 2009). Apart from this, Ceratium is known for its sensitivity to temperature in terms of biogeography (Dodge \& Marshall 1994), seasonality and morphology (Sournia 1967). Ceratium has been considered to be a biological indicator of water masses (Dodge 1993; Raine et al. 2002; Tunin-Ley et al. 2009), current regimes (Dowidar 1973) and climate change (Dodge \& Marshall 1994; Johns et al. 2003). In the present paper, diversity and record of the species Ceratium has been investigated in the Indian part of the Sundarban estuary to offshore Bay of Bengal and discussed in the context of ecological change, particularly the change in Sea Surface Temperature (SST).

\section{Materials and Methods}

Water samples were collected from different stations from the case 2 water of Hooghly estuary and offshore off Bakkhali-Frasergunje (Fig. 1). The depth of the water varies between 1 to $10 \mathrm{~m}$ along a $10 \mathrm{~km}$ radial vector off the coast. The cruise was conducted in the months of January and February, 2009, as December, January and February are the bloom forming seasons for most of the phytoplankton in Sundarban (Biswas et al. 2004). Day time SST data, obtained from Moderate Resolution Imaging Spectro Radiometer (MODIS) with a wave length of $11 \mu$ and spatial resolution of

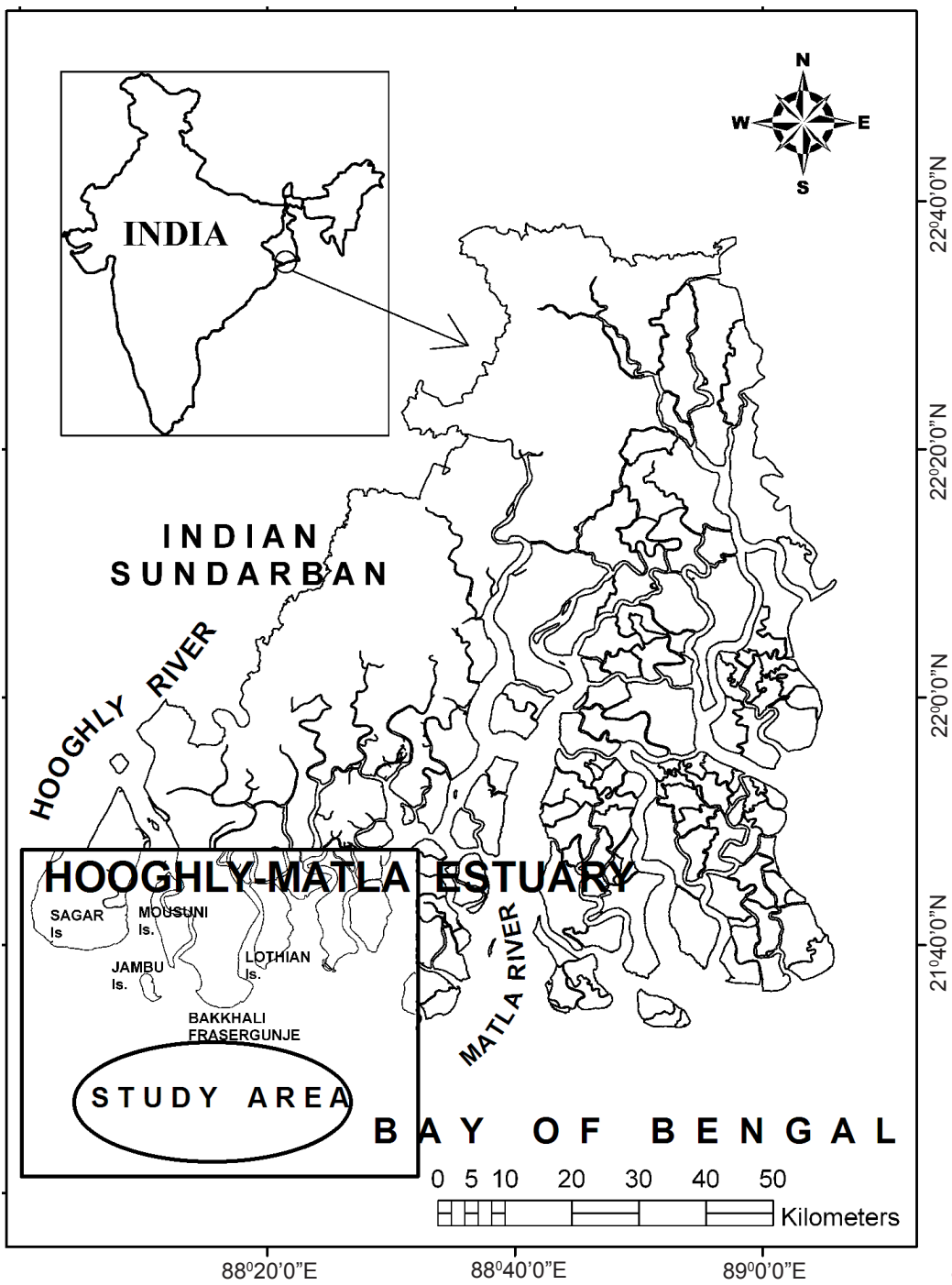

Figure 1. Sampling location of phytoplankton in the Hooghly-Matla estuary and offshore of Indian Sundarban. 
$4 \mathrm{~km}$ has been used in a $1^{0} \times 1^{0}$ grid around the study area. The monthly composite data were derived from the year 2003 to 2009 for the months of January and February. Salinity, $\mathrm{pH}$ and temperature were measured using a portable refractometer (Model no.RHS10(ATC)), a digital pH meter (Model no. pHTestr 1, Eutech instruments, Oakton Instruments) and a digital thermometer respectively. Dissolved oxygen was measured using Winkler's titrimetric method. The transparency of the water column was measured with the help of a Secchi disc. Phytoplankton samples were collected by plankton net of $20 \mu$ mesh size fitted to a wooden stick. Known volume of water was passed through it with a five litre bucket. Plankton samples were preserved in Lugol's iodine solution and sent back to laboratory within 48 hours where it was counted by a Sedgewick Rafter counting cell. The identification of phytoplankton species was done with the help of standard manuals and literature (Tomas 1996; Verlencar \& Desai 2004). Relative abundance (RA) was calculated using the formula:

RA of species X $(\%)$ of Ceratium $=($ No. of species X of Ceratium in each known volume of sample $\times 100$ ) / No. of total Ceratium species in the same volume.

\section{Results}

All together, five species of Ceratium were identified in the months of algal bloom. Ceratium furca (Ehrenberg) Clapar de \& Lachmann, Ceratium fusus (Ehrenberg) Dujardin, Ceratium trichoceros (Ehrenberg) Kofoid, Ceratium tripos (O.F. Mialler) Nitzsch and Ceratium symmetricum Pavillard have been found when the day temperature of the surface water ranged between $24.5-25.2{ }^{\circ} \mathrm{C}$, $\mathrm{pH}$ between 8.0-8.3, salinity between $26-27 \mathrm{ppt}$, dissolved oxygen between $4.7-5.2 \mathrm{mg} / \mathrm{L}$ and total alkalinity (TA) between $125-150 \mathrm{mg} / \mathrm{L}$. The least transparency of the water column was observed to be $39 \mathrm{~cm}$ during the course of sampling (Table 1). Relative abundance was calculated for each species (Table 2), and showed highest abundance of Ceratium furca, followed by $C$. fusus, C. tripos, C. trichoceros and C. symmetricum.

Four out of 10 species of Ceratium, reported from the Indian Sundarban earlier (Santra et al. 1991; Mitra et al. 2003; Biswas et al. 2009) was also found in the present study. The fifth species found in this study, $C$. symmetricum (Image 1) was not reported previously from the Indian Sundarban.
Table 1. The range of physico-chemical parameters observed during the study period

\begin{tabular}{|l|c|}
\hline Parameters & Range \\
\hline Sea surface temperature $\left({ }^{\circ} \mathrm{C}\right)$ & $24.5-25.2$ \\
\hline $\mathrm{pH}$ & $8.0-8.3$ \\
\hline Salinity $(\mathrm{ppt})$ & $26-27$ \\
\hline Dissolved Oxygen $(\mathrm{mg} / \mathrm{l})$ & $4.7-5.2$ \\
\hline Total Alkalinity $(\mathrm{mg} / \mathrm{l})$ & $125-150$ \\
\hline Secchi depth $(\mathrm{cm})$ & $39-151$ \\
\hline
\end{tabular}

Table 2. Relative Abundance (mean \pm standard deviation) of five species of the genus Ceratium Schrank

\begin{tabular}{|l|c|}
\hline Name of the species & Relative Abundance (mean \pm SD) \\
\hline Ceratium furca & $37.7 \pm 4.2$ \\
\hline Ceratium fusus & $24.2 \pm 3.5$ \\
\hline Ceratium tripos & $21.5 \pm 4.8$ \\
\hline Ceratium trichoceros & $13.4 \pm 1.2$ \\
\hline Ceratium symmetricum & $3.2 \pm 0.2$ \\
\hline
\end{tabular}

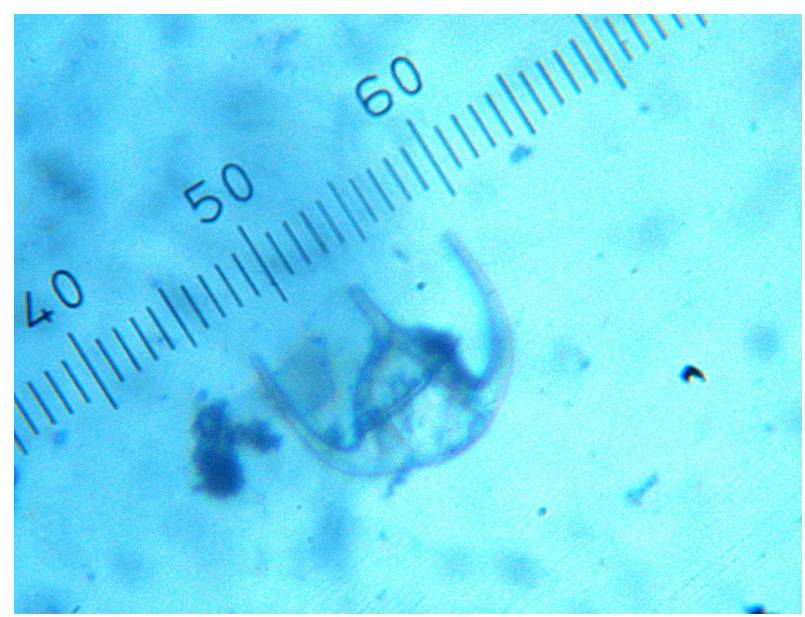

Image 1. Ceratium symmetricum

The analytical data of the monthly composite SST for seven years (2003 to 2009) derived from satellite images within the study area for the months of January and February (24.114 and $25.495{ }^{\circ} \mathrm{C}$ respectively) clearly depicts an increased winter SST in the year 2009, than the previous years (Figs. $2 \& 3$ ). The temperature difference is also maximum between 2008 and 2009 (during January and February), within the last seven years. 


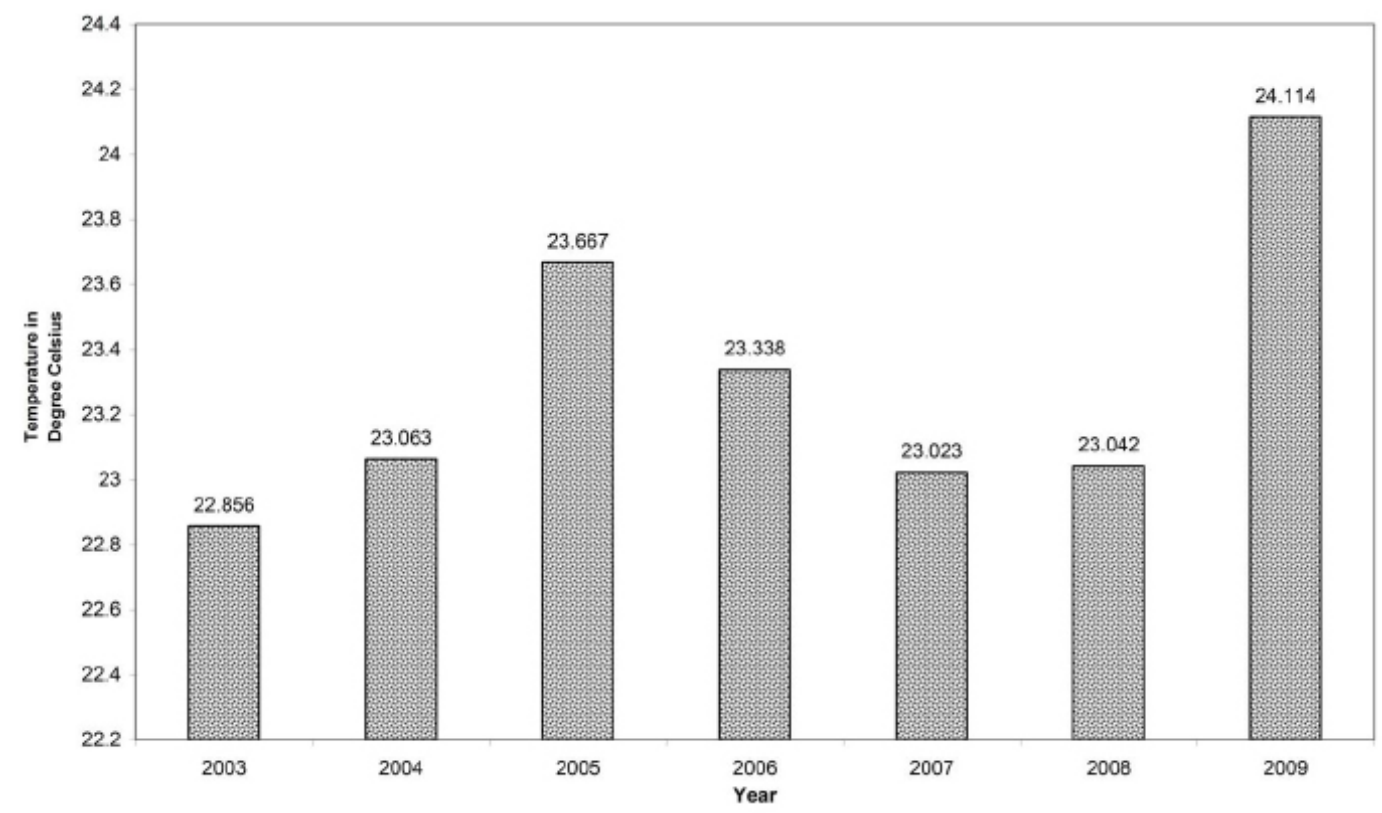

Figure 2. Change of SST in the month of January from 2003 to 2009 around the study area $\left(1^{\circ} \times 1^{\circ}\right)$

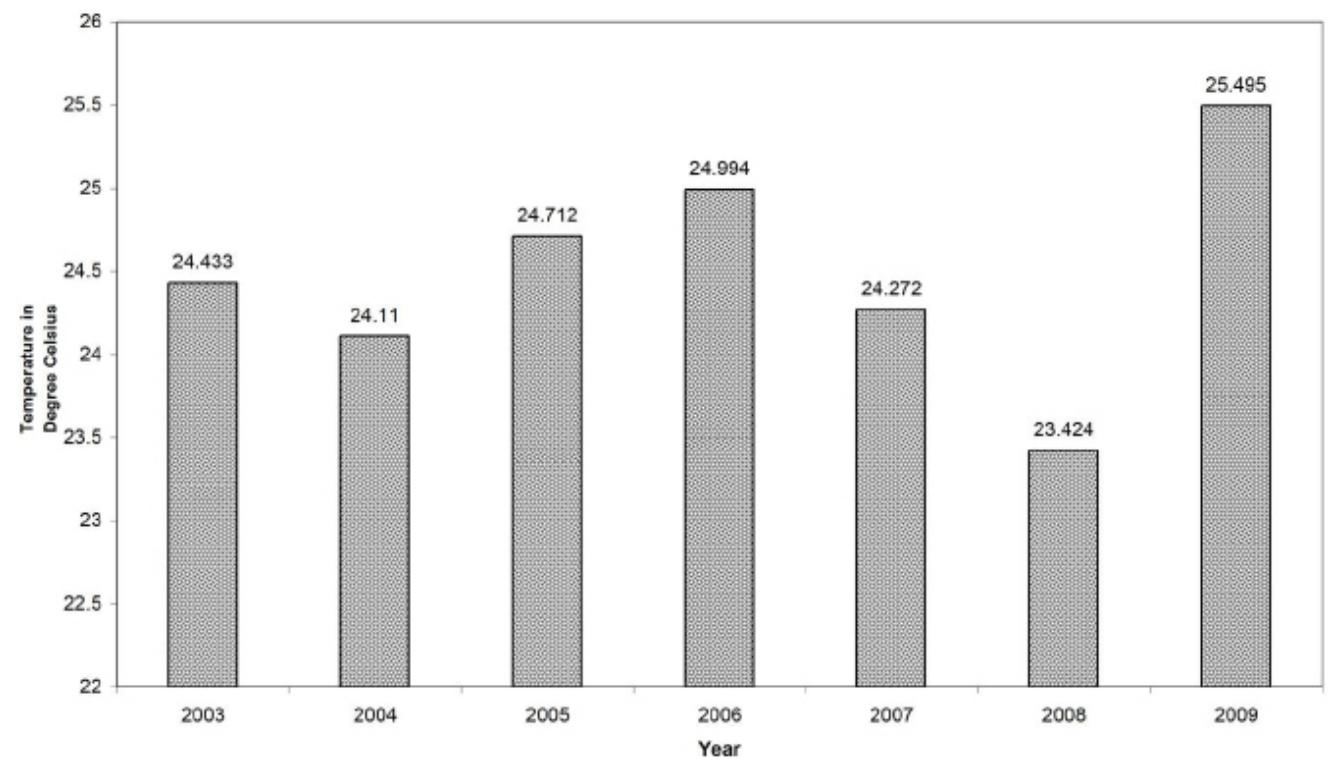

Figure 3. Change of SST in the month of February from 2003 to 2009 around the study area $\left(1^{\circ} \times 1^{\circ}\right)$

\section{Discussion and Conclusions}

The distributions of $C$. symmetricum are comparatively limited and are reported in warm temperate to tropical waters (Parke \& Dixon 1976; Gil-Rodriguez et al. 2003). The species was reported from the water column of continental shelf of northern and northwestern Australia (Hallegraeff \& Jeffrey 1984) and northwestern Mediterranean Sea (TuninLey et al. 2009).

Several types of biological indicators of ecological change have been suggested, for example, abundance of individual taxa, functional attributes of the ecosystem, species assemblages and phenological traits (Beaugrand 2005). Among the species of Ceratium found in this study, available literature suggests: $C$. furca and C. tripos are perennial, whereas C. fusus is almost perennial since it may be absent only for a couple of months. C. trichoceros is one of the species which is not specifically associated with any depth or environment (Tunin-Ley et al. 2009). Among these 
species, mixotrophic behavior has been observed in $C$. furca (Smalley et al. 1999) and C. fusus (Mikaelyan \& Zavyalova 1999). Mixotrophic organisms are theoretically supposed to be, less dependent on nutrient availability and irradiance (Tunin-Ley et al. 2009).

Tunin-Ley et al. (2009) have revealed in their work that the diminished occurrence of certain Ceratium species during the warm season (in case of northwestern Mediterranean Sea) in surface water is an important sign of change. Among these, C. teres, in the main and $C$. symmetricum and $C$. horridum to a lesser extent, could be proposed as indicators of warming since they seemed to be limited by a maximum temperature threshold. The temperature of the northwestern Mediterranean Sea in the warm season $\left(23^{\circ} \mathrm{C}\right.$ in summer, 2002 , and above $25^{\circ} \mathrm{C}$ in summer, 2003 (Tunin-Ley et al. 2007) is comparable to the temperature $\left(24.5-25.2{ }^{\circ} \mathrm{C}\right)$ of our study area in the winter as measured during the study period. Thus, similar inferences can be drawn from the present study of limited abundance of C. symmetricum in the estuary and offshore of Indian Sundarban.

Ceratium symmetricum was found to be much reduced in number (Relative Abundance: $3.2 \pm 0.2$ ) compared to the other four species during winter (Table 1), indicating its lesser compatibility with the physico-chemical features, especially with SST in the study area. The other four species are less responsive to warming and tolerant of a wide range of physical condition, whereas the occurrence of a reduced number of $C$. symmetricum may be indicative of temperature rise in the Sundarban estuary and offshore.

It is proposed that, long term monitoring of thermal preference or sensitivity of species of Ceratium along with various physicochemical features of water can be a useful approach for the analysis of the impact of climate change on the phytoplankton community of the northern Bay of Bengal. This study, thus, opens some new avenues for generation of a long term dataset which would throw some light on various aspects of Sundarban's mangrove ecosystem and climate change induced impact on them.

\section{REFERENCES}

Banerjee, A., \& S.C. Santra (2001). Phytoplankton of the rivers of Indian Sunderban mangrove estuary. Indian Biologist 33(1): 67-71.
Beaugrand, G. (2005). Monitoring pelagic ecosystems using plankton indicators. ICES Journal of Marine Science 62: 333-338.

Biswas, H., S.K. Mukhopadhyay, T.K. De, S. Sen \& T.K. Jana (2004). Biogenic controls on the air-water carbon dioxide exchange in the Sundarban mangrove environment, northwest coast of Bay of Bengal, India. Limnology and Oceanography 49(1): 95-101.

Biswas, H., M. Dey, D. Ganguly, T.K. De, S. Ghosh \& T.K. Jana (2009). Comparative analysis of phytoplankton composition and abundance over a two-decade period at the land-ocean boundary of a tropical mangrove ecosystem. Estuaries and Coasts DOI 10.1007/s12237-009-9193-5.

Dodge, J.D. (1993). Biogeography of the planktonic dinoflagellate Ceratium in the Western Pacific. Korean Journal of Phycology 8: 109-119.

Dodge, J.D. \& H.J. Marshall (1994). Biogeographic analysis of the armoured planktonic dinoflagellate Ceratium in the North Atlantic and adjacent seas. Journal of Phycology 30: 905-922.

Dowidar, N.M. (1973). Distribution and ecology of Ceratium egypticum Halim and its validity as an indicator of the current regime in the Suez Canal. Journal of Marine Biological Association of India 15: 335-344.

Gil-Rodriguez, M.C., R. Haroun, A.O. Rodriguez, E.B. Zugasti, D.P. Santana \& B.H. Moran (2003). Proctotista, pp. 5-30. In: Moro, L., J.L. Martin, M.J. Garrido \& I. Izquierdo (eds.). Lista de especies de Canarias (algas. Hongos, plantas y animales).

Hallegraeff, G.M. \& S.W. Jeffrey (1984). Tropical phytoplankton species and pigments of continental shelf waters of North-West Australia. Marine Ecology Progress Series 20: 59-74.

Johns, D.G., M. Edwards, A. Richardson \& J.I. Spicer (2003). Increased blooms of a dinoflagellate in the NW Atlantic. Marine Ecology Progress Series 265: 283-287.

Lepisto, L., A. Holopainen \& H. Vuoristo (2004). Type specific and indicator taxa of phytoplankton as a quality criterion for assessing the ecological status of Finnish boreal lakes. Limnologica 34: 236-248.

Mikaelyan, A.S. \& T.A. Zavyalova (1999). Vertical distribution of heterotrophic phytoplankton in the black sea during the summer period. Oceanology Russian Academy of Science 39: 893-902.

Mitra, A., D.P. Bhattacharya \& K.Banerjee (2003). Introduction to marine plankton. Narendra Publishing House, Delhi.

Paerl, H.W. (2006). Assessing and managing nutrient-enhanced eutrophication in estuarine and coastal waters: Interactive effects of human and climatic perturbations. Ecological Engineering 26: 40-54.

Parke, M. \& P.S. Dixon (1976). Checklist of British marine algae - 3rd revision. Journal of the Marine Biological Association of the United Kingdom 56: 527-594.

Raine, R., M. White \& J.D. Dodge (2002). The summer distribution of net plankton Dinoflagellates and their 
relation to water movements in the NE Atlantic Ocean, West of Ireland. Journal of Plankton Research 24: 1131-1147.

Santra, S.C., U.C. Pal \& A. Choudhury (1991). Marine phytoplankton of the mangrove delta region of West Bengal, India. Journal of Marine Biological Association of India 33(1\&2): 292-307.

Sen, N. \& K.R. Naskar (2003). Algalflora of Indian Sundarban. Daya Publishing House, Delhi.

Smalley, G.W., D.W. Coats \& E.J. Adam (1999). A new method using microspheres to determine grazing on ciliates by the mixotrophic dinoflagellate Ceratium furca. Aquatic Microbial Ecology 17: 167-179.

Sournia, A. (1967). Le genre Ceratium (Péridinien planctonique) dans le canal du Mozambique. Contribution á une révision mondiale. Vie Milieu Serie A-Biologie Marine 18: $375-500$

Nielsen, E.S. \& E.A. Jensen (1957). Primary Oceanic Production. Galathea Report, Gopenhagen, Denmark, 1:
49-136 pp.

Tomas, R.C. (1996). Identifying marine phytoplankton. Academic Press, Inc. Harcourt Brace \& Company, London.

Tunin-Ley, A., J.P. Labat, S. Gasparini, L. Mousseau \& R. Lemée (2007). Annual cycle and diversity of species and infraspecific taxa of Ceratium (Dinophyceae) in the Ligurian Sea, northwest Mediterranean. Journal of Phycology 43: 1149-1163.

Tunin-Ley, A., F. Ibanez, J.P. Labat, A. Zingone \& R. Leme_e (2009). Phytoplankton biodiversity and NW Mediterranean Sea warming: changes in the dinoflagellate genus Ceratium in the $20^{\text {th }}$ century. Marine Ecology Progress Series 375: 85-99.

Verlencar, X.N. \& S. Desai (2004). Phytoplankton Identification Manual. National Institute of Oceanography, Dona Paula, Goa. 